\title{
An Application of Quantitative Geomorphometric Indicators in identifying '[Susceptible Zones by Using SVM Model (Case study: Khorramabad-Pol Zal Freeway)
}

\author{
Ali Ahmadabadi \\ Kharazmi University \\ Mitra Saberi ( $\nabla$ msaberi.khu@gmail.com ) \\ Kharazmi University https://orcid.org/0000-0002-5841-2783
}

\section{Research}

Keywords: Quantitative Geomorphometric, SVM Model, Pol Zal Freeway

Posted Date: January 29th, 2021

DOI: https://doi.org/10.21203/rs.3.rs-154476/v1

License: (c) (1) This work is licensed under a Creative Commons Attribution 4.0 International License. Read Full License 
4 An Application of Quantitative

5 Geomorphometric Indicators in identifying '[Susceptible Zones by Using SVM Model (Case 7 study: Khorramabad- Pol Zal Freeway)

8

9

\section{Abstract}

Geomorphomety is the quantitative measurement of landforms based on height changes influenced by distance function. Geomorphomety indices express the characteristics of the terrain quantitatively. The present study emphasizes the use of geo-morphometric parameters and SVM algorithm to identify areas prone to landslide in Khorramabad- Paul Zal freeway as one of the important roads in the country. Other indices include slope, aspect, lithology, fault condition, drainage and land use which are applied together with the geometric indices such as profile curvature, plan curvature and total curvature use, artificial intelligence approach and linear functions and polynomial SVM algorithm to identify areas prone to landslides. The results show using Geomorphometric indices play an important role in increasing accuracy of assessing and identifying areas with an increasing the risk of landslides and assessing the accuracy through using land survey data shows that polynomial functions are more accurate in identifying areas prone to landslides than SVM algorithm linear function.

1. Assistant prof. in Geomorphology, Kharazmi University, ahmadabadi@khu.ac.ir.

2. PhD of Geomorphology, Kharazmi University ,msaberi.khu@ gmail.com. 


\section{Introduction}

33 Landslide has a negative effect on human life and 34 economic activities all over the world 35 (Pourghasemi et al., 2012, Nadim et al., 2006). 36 According to 2012 World Disaster Report (201137 2002) landslide is among the world's seven natural 38 disasters (IFRCRCS., 2012). Several methods have 39 been proposed to evaluate the landslide 40 susceptibility map that can be divided into two 41 broad classification categories: qualitative 42 (subjective) and quantitative (objective) (Fell et al., 43 2008). However, Landslides are usually complex 44 systems and to predict the sensitivity of their 45 occurrence there needs to be different 46 geomorphologic, geologic, hydrological, land cover 47 and other data on environmental factors (Ling Peng 48 et al., 2014). There are no specific universal 49 guidelines for the selection of the factors affecting 50 global mapping of landslide susceptibility (Yalcin., 51 2008). Previous studies were usually willing to 52 provide little information or a model with low 53 quality performance (Guzzetti et al., 2006; Frattini et al., 2010)which were not satisfactory for final users and there were limitations associated with these studies) Chung and Fabbri., 2003). This is the necessity because of which methods with better criteria for identifying significant environmental factors leading to landslide in line with the environmental planning are needed. With regard to improved methods of data analysis and technical and artistic techniques such as of Artificial Neural Networks (Lee et al., 2004; Yesilnacar and Topal., 2005; Nefesliogluet al., 2008), fuzzy logic (Ercanoglu and Gokceoglu., 2004; Pradhan et al., 2009; Akgun et al., 2012), neural - fuzzy, (Oh and Pradhan, 2011; Bui et al., 2012) Decision tree (Saito et al., 2009; Wan., 2009; Nefeslioglu et al., 2010; Yeon et al., 2010) algorithm and support Mashyn $\neg$ Brdar Yao et al., 2008; Yilmaz., 2009; Marjanovi'c et al., 2011; Pradhan., 2013) The researchers were able to use these techniques for mapping the landslide. Yamani et al (2013) in a study in Darakeh basin, performed the landslide zoning using four functions of SVM algorithm. The results showed that through identifying areas prone to landslide, the external function of this algorithm best matches the reality. In another study, Chan $\mathrm{Su}$ and et al (2012) examined the ability of the SVM model in landslides caused by earthquakes using GIS software in China's Jianjiang Basin. The results suggest more appropriate radial function SVM algorithm in comparison to other functions, in predicting of landslides. A review of the literature in this area suggests few studies have been done on the involvement of the scope and impact geomorphometic indicators. Among such limited studies, one can mention the research
Talebi and et al (2008) have done; He combined three longitudinal profiles (concave, flat and convex) and three types of plans (convergent, parallel and divergent) to provide the domain model for slope stability of the composition. In this model, the impact of the plans and profiles was investigated in unstable slopes and landslides. According to the results, it can be said that the slope of the convex and concave divergent and convergent are generally more stable than the steep, smooth slope, while the other two are located on the intermediate level. So far, there have been no comprehensive studies of landslide susceptibility assessment in the study area.

Furthermore, the limited information about the area, has not let us do a survey to assess the exact number of potential landslides. landslides occurred on Khorramabad - Pol Zal highway in south west of Iran (Figure 1) and near the historic landslide Simereh which is a serious threat to social and economic stability of the region; As a result of the construction of the main road which connects the central and western regions of Iran Khuzestan plain and the Persian Gulf, new trenches in susceptible geological formations, has increased the probability of potential landslides and slope instability, which has become a serious and inevitable problem (Yamani et al., 2014). That's why the prediction of landslides so as to prevent new landslide, new slips and also activation of older landslides, it is essential to reduce the risk of the zone. The purpose of this study is to evaluate SVM method to identify landslide prone zones with emphasis on the use of Geomorphometric parameters.

\section{Extent of the study}

The newly built Khorramabad - Paul Zal highway with a length of $104 \mathrm{~km}$, connects the city of Khorramabad to Andimeshk. Beginning of the path has of latitude 3326 Northern and a longitude of 4812 East is the direction of latitude 32485 Northern and longitude 4804 Eastern passes. This ranges from the northwest to the southeast of the Zagros Folded Belt clash and is part of the Himalayan Alps Upper Cretaceous platform that converges the Arabian and Eurasian there (Talbot \& Alavi., 1996). The aforementioned path with an area of $480 / 968 \mathrm{KM}^{2}$; is like a strip of variable width from 5 to $7 \mathrm{~km}$ that has been chosen based on the occurrence of landslides and their impact that can be dominant on the road slopes. The roads are often built in the mountains and at the confluence of the valleys, and they pass over embankments or bridges. The starting point of the 
semi-arid (Yamani et al., 2014). The average annual rainfall is between $322-578 \mathrm{~mm}$ which varies from north to south. Geomorphological construction of the region can be divided into Northern and Southernareas by thrust fault RitSultan. Differences in the extent and severity of folds and faults in tectonic result is of significant difference in both North and South Northern regions. 

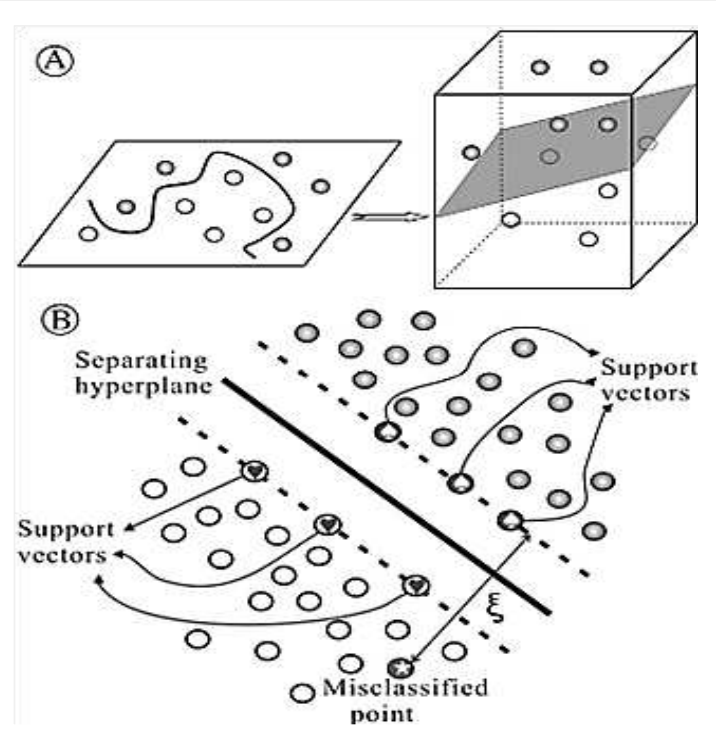

Fig. 2 Image of the principles of SVM(A) n-dimensional Page differences between the two classes with a maximum distance(B) The inseparable and imprecise variables

224 Which is subject to the following restrictions:

Details of the two-class SVM modeling is summarized as follows (Yao et al., 2008):

Given a set of distinct cell line

$$
f X_{i}(i=1,2, \ldots, n)
$$

Cells which include two classes as $y_{i}= \pm 1$ Marked. The purpose of SVM model is to Find a distinction between two classes $-\mathrm{N}$ size, which is determined by the maximum gap. Mathematically, this concept can be taken with these words:

$$
\frac{1}{2}\|W\|^{2}
$$

$$
\left.Y_{i}\left(\left(W \cdot X_{i}\right)\right)+b\right) \geq 1
$$

$\|W\|$ is the rule of a normal a numeric base and (.)Specifies the number of production operation. Using coefficient of Lagranzhyan the value of performance can be defined as follows:

$\mathrm{L}=\frac{1}{2}\|\mathrm{~W}\|^{2}-\sum_{i=1}^{n} \lambda i\left(y_{i}\left(\left(w x_{i}\right)+\mathrm{b}\right)-1\right)$

$\lambda i$ is a Lagranzhyan coefficient. This solution can be calculated through minimization of binary equation 3. Variation of variables bles B \& W took place in standard valuation methods:
236

$\lambda i\left(y_{i\left(\left(w x_{i}\right)+\mathrm{b}\right)} \geq 1-\xi_{i}\right.$

$$
\mathrm{L}=\frac{1}{2}\|\mathrm{~W}\|^{2}-\frac{1}{v n} \sum_{i=1}^{n} \xi_{i}
$$

\section{Geomorphometric indicators of the range}

240 Geomorphometric characteristics express the shape 241 of ranges which are prone to slip quantitatively. 242 Using values obtained from the DEM products 243 such as slope, profile curvature, plan curvature, 244 width curvature, and the general curvature of range 245 morphometric characteristics of landforms 246 (landslide) (Fisher et al., 2004; Pike., 2000; 247 Wood1996). Convexity and concavity and second 248 derivatives with respect to the levels that are 249 generally known under the name of curvature and 250 curvature can be used to measure the roughness of 251 the surface. The amount of curvature in different 252 types in the raster digital elevation model is 253 calculated pixel by pixel and for each cell of a 254 fourth degree polynomial equation is used 255 (Relationship between 1, 2 and 3). In a window 256 with dimensions of $3 \times 3$ is calculated (Figure 3). 257 Since the curvature has been calculated using a 258 moving window of eight neighboring cells it is 259 possible to identify cells and concave and convex 260 surfaces there.

261 Equation 1: general of curvature

$262 Z=A x^{2} y^{2}+B x^{2} y+C x y^{2}+D x^{2}+E y^{2}+F x y+G x+H y+I$ 


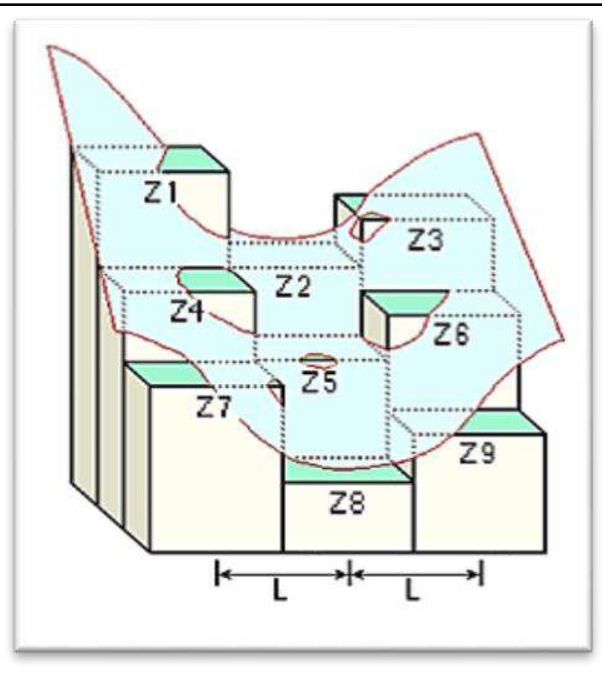

Fig. 3 Schematic representation of the parameters used in calculating the overall of curvature

265

274 Equation 2-2: the curvature profile.

$275 \mathrm{n} * \mathrm{~g} *\left(\mathrm{a} * \mathrm{~d}^{2}+\mathrm{b} * \mathrm{e}^{2}+\mathrm{c} * \mathrm{~d} * \mathrm{e}\right) /\left(\mathrm{d}^{2}+\mathrm{e}^{2}\right)\left(1+\left(\mathrm{d}^{2}+\mathrm{e}^{2}\right)^{1 . .5}\right.$

276 On the other hand the curvature of the plan

277 represents a shift in direction through a curve, and

278 therefore represents a topographical divergence and

279 convergence. Negative values of the curvature of

280 the plan indicates the current divergence, which

281 includes the ridges and peaks and positive values

282 (valleys) show (Goudie., 1990)current

283 convergence. It is noteworthy that flat surfaces

284 have a curvature of zero. The curvature is measured

285 in radians or in meter (up to $100 \mathrm{~m}$ ).

286 Equation 3: the curvature Plans

$n * g *\left(b * d^{2}+a * e^{2}-c * d * e\right) /\left(d^{2}+e^{2}\right)^{1.5}$
288 In all these relationships g: resolution of digital 289 elevation model, $n$ : the dimensions of the moving 290 window.

\section{Discussion and Results}

292 Map of the existing landslides and the training 293 samples

294 In this study, to determine landslide susceptibility, 295 features of 39 landslides which had occurred in the 296 study area were taken using satellite images (PAN)

297 IRS and geographic information systems (GIS) 298 were analyzed. Samples which were randomly 299 collected from the landslide area were divided into 300 two groups: first those are used for model 301 production training and the examples which were 302 used in model validating tests(Marjanovi'c et al., 303 2011). The main purpose of separating training and 304 testing of samples was building a model and 305 modeling test obtained by independent test 306 samples. When the randomly collected samples for 307 simultaneous training and testing are used with 308 random samples based on the pixel slip spots, the 309 model performance can be artificially increased 310 (Taner San., 2014). 


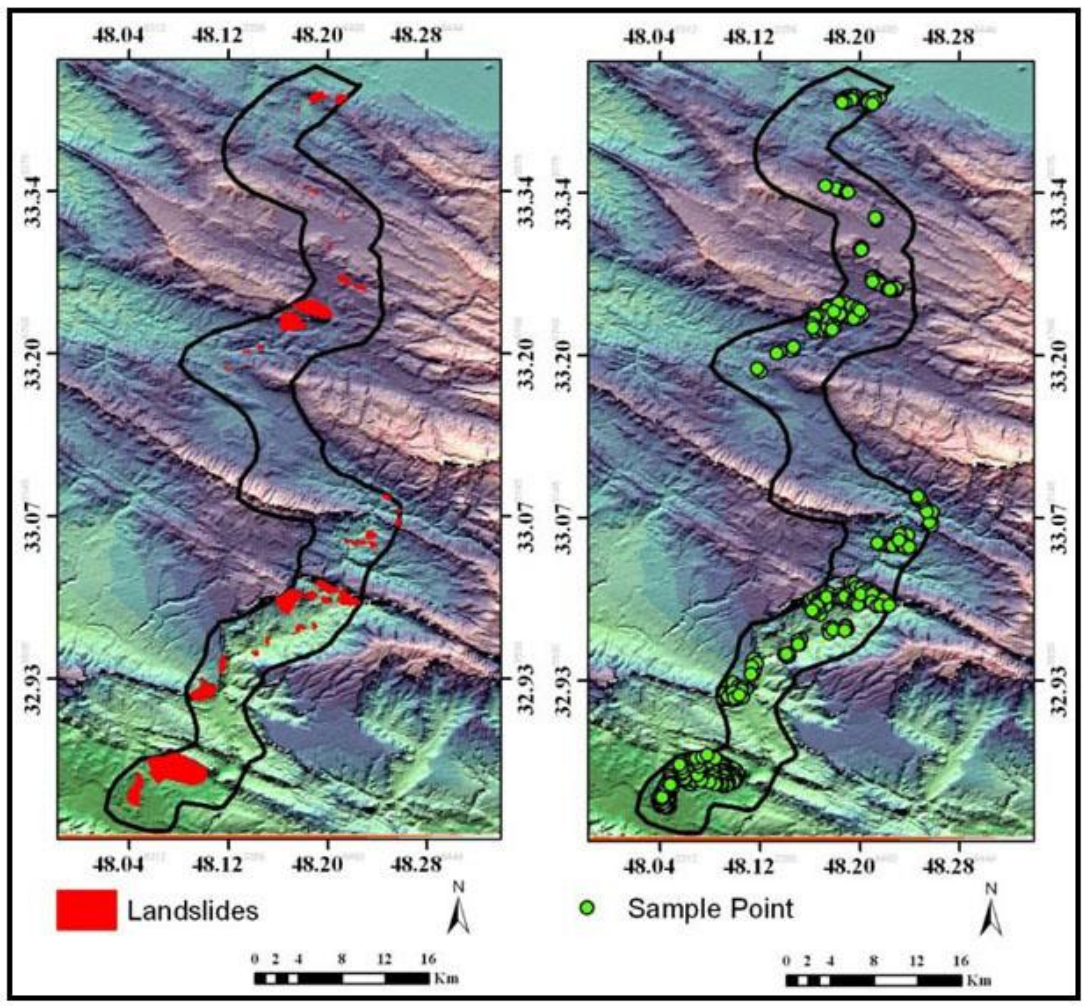

Fig. 4 Distribution of landslides and training samples in the study area

313 zoning the landslide using the controller 314 parameters

\section{6 land use}

337 Freeway construction and excavation and 338 embankment operations together with the

339 destruction of oak forests and meadows, without 340 any attention to principles of sustainability are 341 among the most important factors which stimulate 342 the dominant ranges over roads. In order to provide 343 an efficient map using Landsat TM images were 344 used and the general area was divided into four in 345 which the categories of agricultural lands and 346 gardens, meadows, forests and rocky surfaces.

\section{Distance from drainage}

348 Landslides on the sidelines of most of the 349 waterways in the area, especially around the main 350 river beds of Zal and Chameshk lead to instability 351 of dominant ranges. For this purpose, six floors 352 from long distances to those close to the waterways 353 and rivers in Figure 5 are provided to determine the 354 impact of these variables in case a landslide occurs 355 (Figure 5)

\section{Distance from the fault}

357 In the region, either directly (the energy of the 358 fault) and indirectly (the effect of lithology and 359 slope) landslides are caused by faults. To 360 understand the impact of this parameter buffers 361 were made from a distance of 5 Kilometers to the 362 active fault line, in the form of five stories as $<5$, 363 5-10, 10-15, 15-20,> $20 \mathrm{~km}$ (Figure 5).

\section{Lithology}


365 Lithology is known as a key factor in creating 366 landslide in the form of erosion and weathering

367 (Anbalagan, 1992 Dai et al., 2001). Distribution of
368 rocks in Fig. 4 and the descriptions of each of them 369 is given in Table 1.

370

371 Table1 Geological units and their descriptions in the study area

\begin{tabular}{lcc}
\hline Describing lithology & Geological units & The row number \\
\hline Calcareous sandstone and silty marl with streaks column & MuPlaj & $\mathbf{1}$ \\
The cement conglomerate with limestone and marl & $\mathrm{Plbk}$ & $\mathbf{2}$ \\
Semi-hard conglomerate recent & Qc2 & $\mathbf{3}$ \\
Dolomitic limestone, marl and clay with layers & EMass-Sb & $\mathbf{4}$ \\
Siltstone, sandstone, limestone marl & KPeam & $\mathbf{5}$ \\
Conglomerate sandstone and siltstone with interlayers & Ekn & $\mathbf{6}$ \\
Gypsum and clay marl with anhydrite & Mlgs & $\mathbf{7}$ \\
Marl and shale clay with traces of lime & Kgu & $\mathbf{8}$ \\
Shale and marl with limestone clay & $\mathrm{Pb}$ & $\mathbf{9}$ \\
Songs full of fossils & $\mathrm{Tz}-\mathrm{E}-\mathrm{zang}$ & $\mathbf{1 0}$ \\
Marl clay limestone with shale layers & $\mathrm{Kbgp}$ & $\mathbf{1 1}$ \\
Alluvium and debris recent & $\mathrm{Qt2}$ & $\mathbf{1 2}$ \\
\hline
\end{tabular}

372

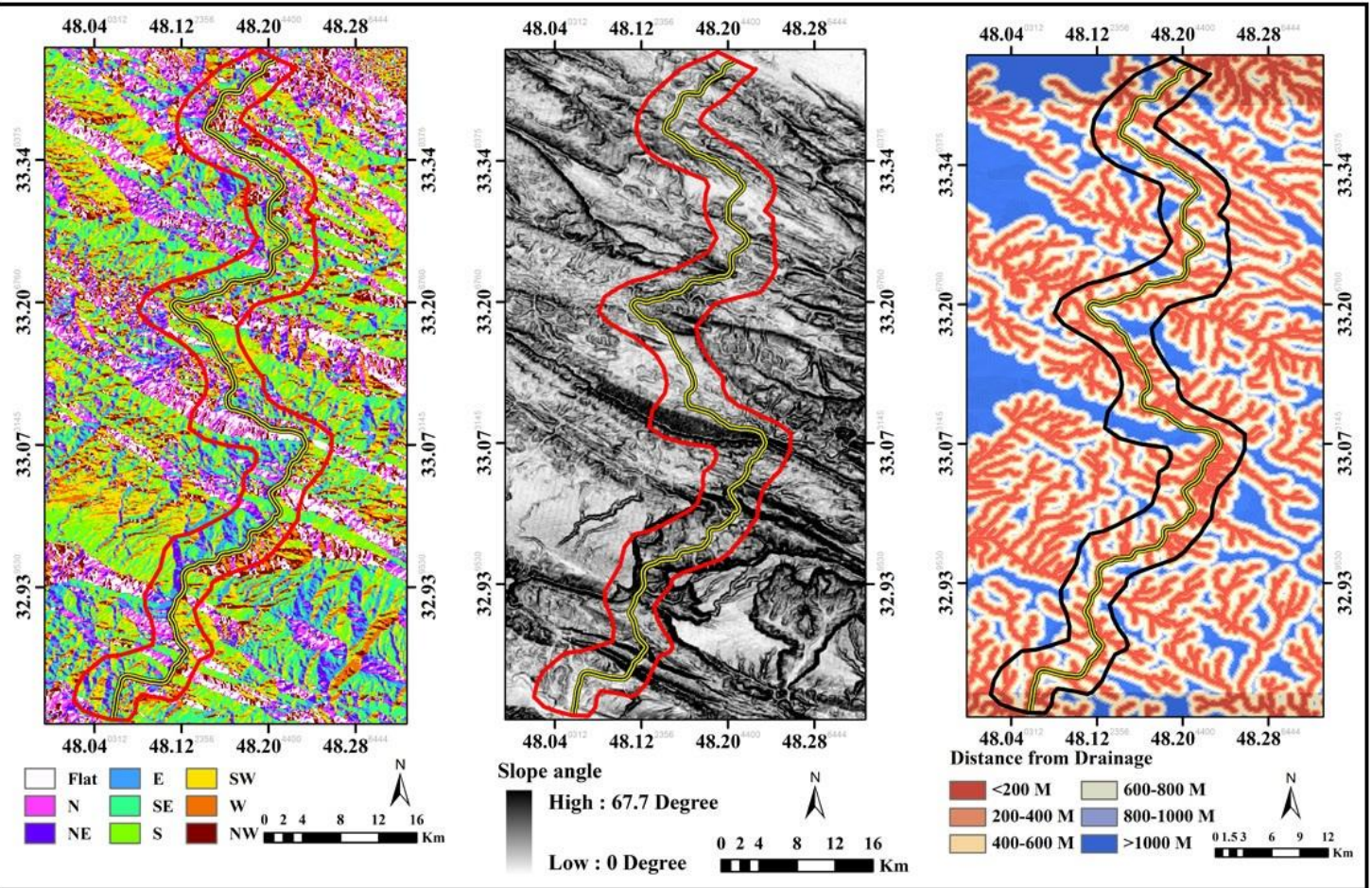




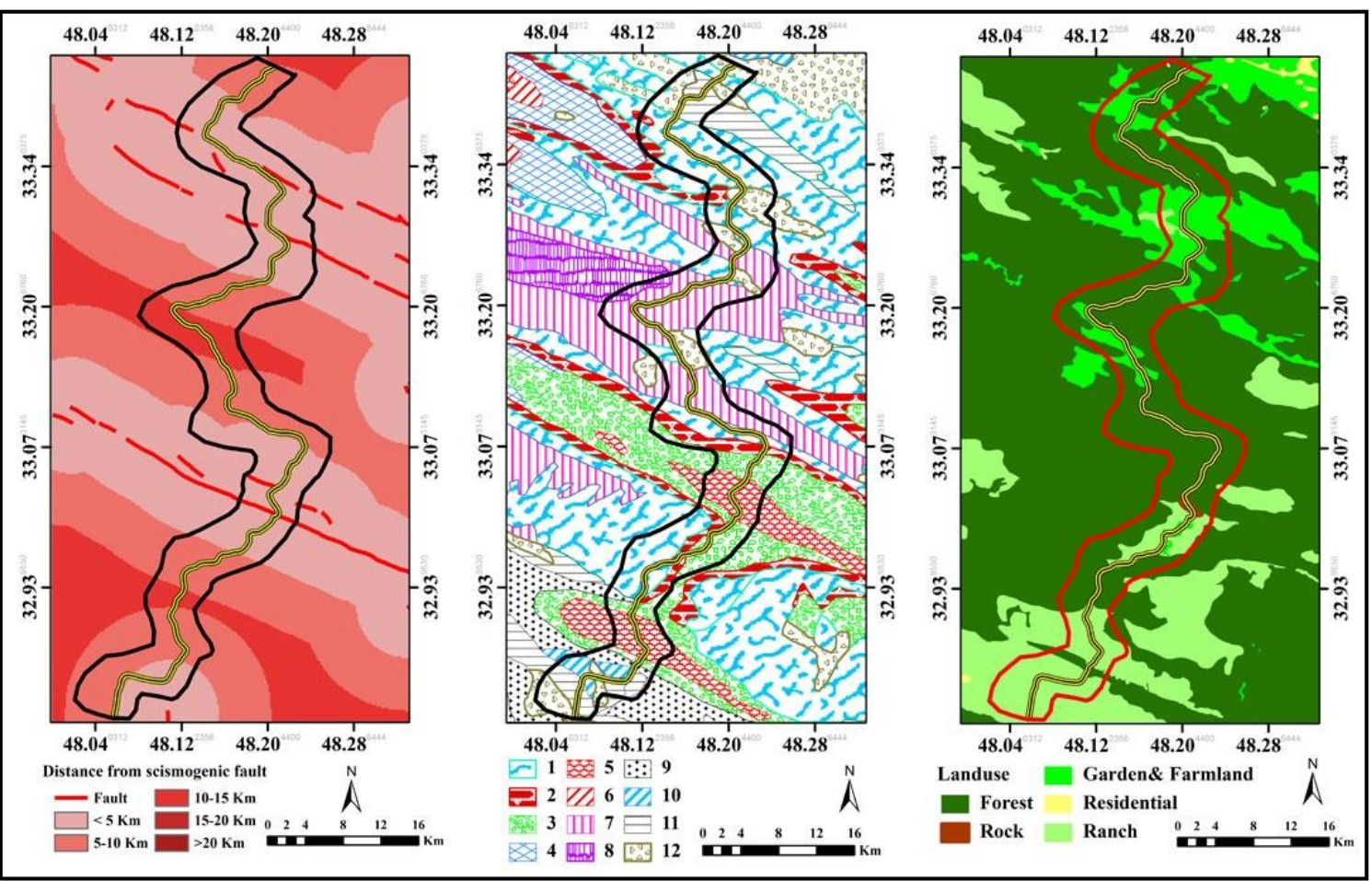

\section{Geomorphometic variables}

377
Rippling type of domains has a significant effect on the occurrence of landslides. In most studies to express rippling effect on the domain movement, slope factor cannot show all the features of uneven surface by itself. Therefore, in this study the Geomorphometic variables of profile curvature, and plan and the overall curvature which are derivatives of second grade were used for expressing roughness of the domain surface and their effect on landslides and an attempt has been made to use them for identifying areas prone to landslides and thus model them more accurately (Figure 6). The curve of the profile represents the
390 amount of change in profile curvature along the 391 way and therefore represents the intensity of water

392 flow and sedimentation and transportation 393 processes. Thus the amounts of negative curvature 394 show convex surfaces and concave surfaces are 395 shown by a positive amount. On the other hand, the 396 curvature of the plan represents a shift in direction 397 of the curve, and therefore represents a 398 topographical divergence and convergence. 399 Negative values of the curvature of the plan show 400 the current divergence, which includes the ridges 401 and peaks and positive values show flow 402 convergence (valleys). The overall curvature 403 specifies the overall shifts in the surface. 

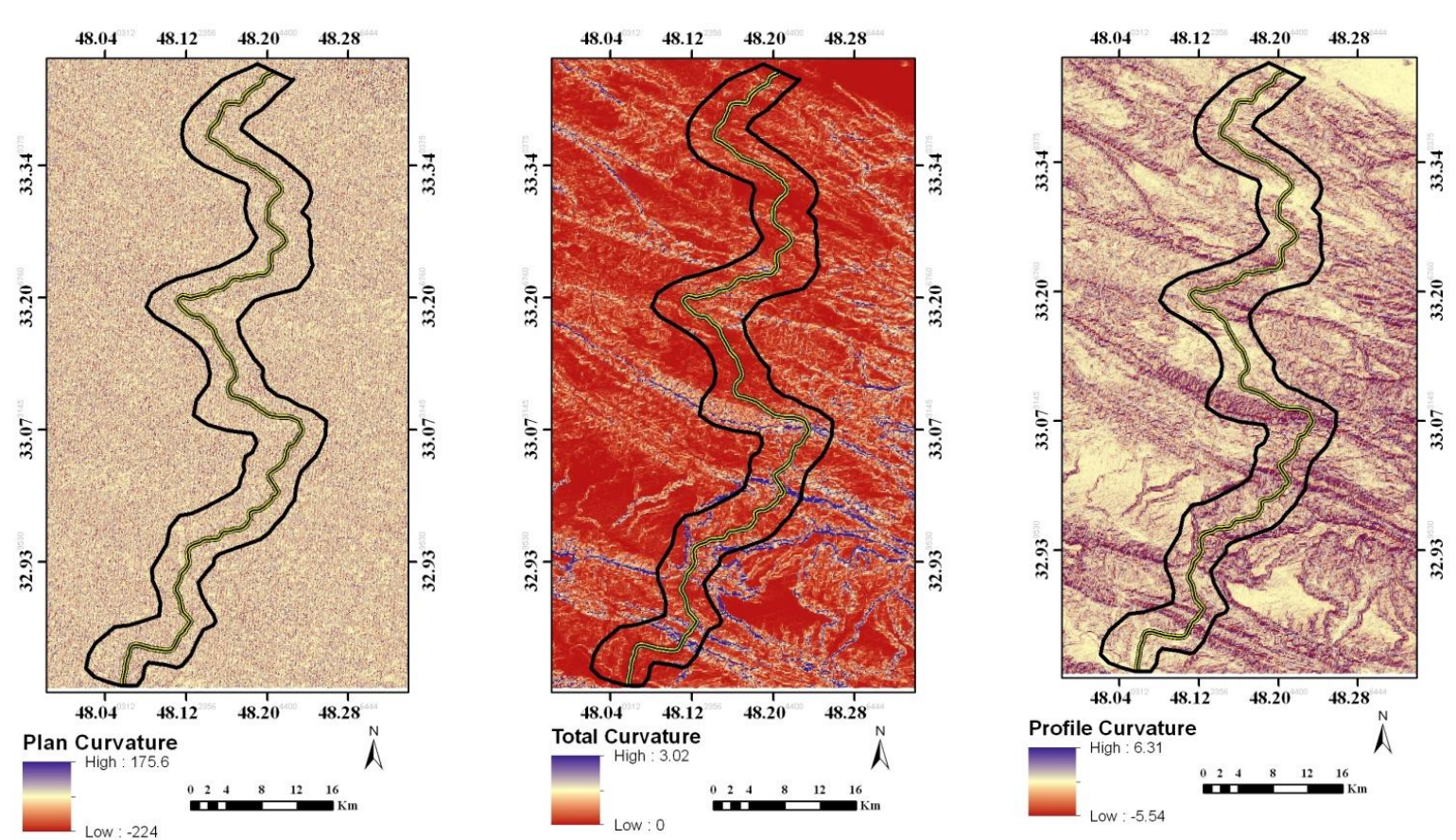

Figure 6 Geomorphomety variables controlling landslides in the study area

405
415 got closer to 1 (Light Color on the map) aptness 416 and sensitivity for landslides in the study area 417 increases. The results show that more than 30 418 percent of the area under study, is located in areas 419 with more than 0.8 which indicates that the high 420 sensitivity of the study area of the slip. One reason 421 to the high sensitivity of the area is the passage of 422 the highway and cutting off the range and finally a 423 loss of balance in the region. 


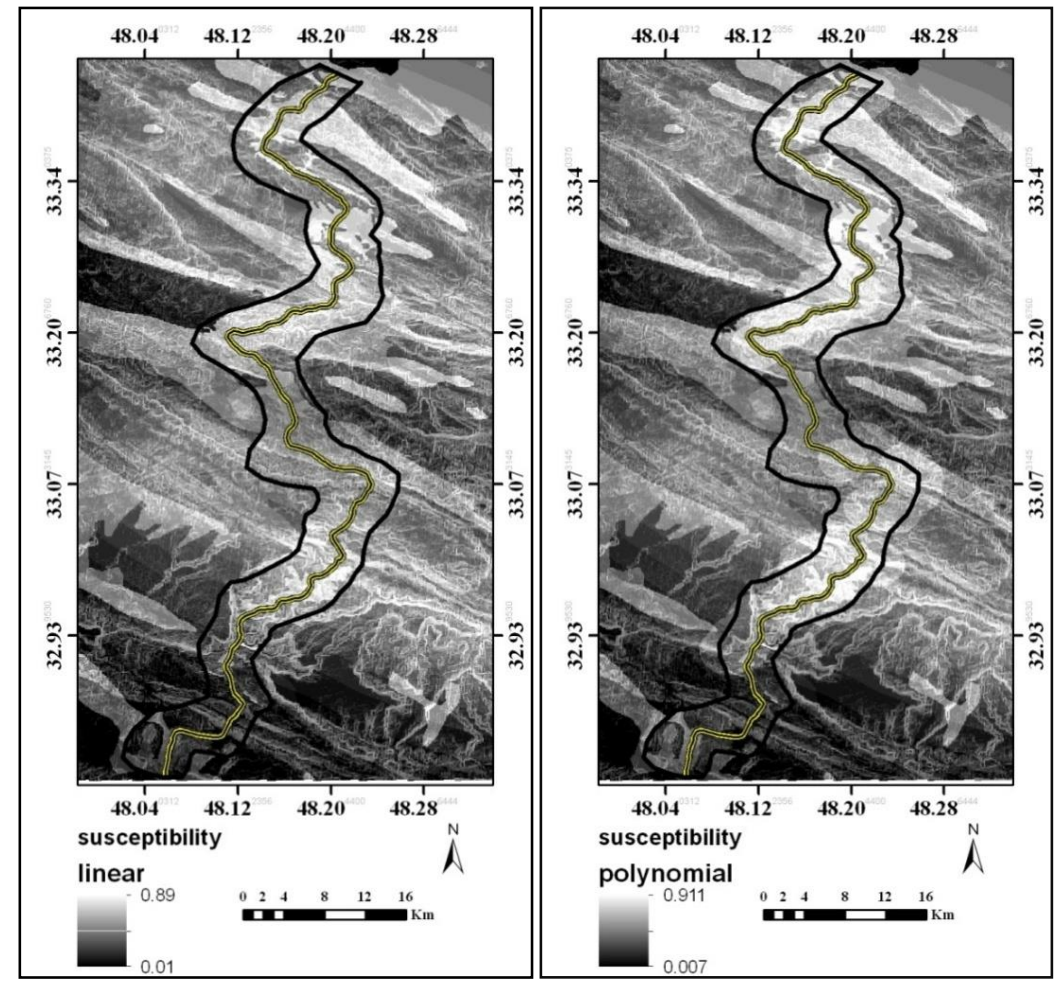

427 assessment of accuracy of slip zoning 428 modeling

429 After application of each model, it is necessary to 430 evaluate the accuracy to take action regarding the 431 applicability and reality of results. In this study, 432 twenty percent of the samples were used to assess 433 accuracy carefully. First, an error matrix was 434 formed and then using the overall accuracy, 435 accuracy of the model was determined. The results 436 show modeling through by polynomial function 437 (polynomial) with an overall accuracy of $89 \%$ was 438 more accurate and had a better performance and is 439 more consistent with ground realities in comparison 440 to the linear method with an overall accuracy of $44184 \%$. Given that the behavior of the slip control 442 variables in the study area has not been linear and 443 has a non-linear complex behavior, Polynomial 444 method has had a better modeling capability and 445 mapping results are more compatible with the 446 ground reality.

\section{Conclusion}

448 Geomorphomety is the quantitative analysis of the 449 shapes on the surface of the Earth and land surface 450 conditions which carries out the quantitative 451 analysis of uneven surfaces. In this study, the 452 aforementioned indicators along with other 453 variables have been used, in order to identify more
454 precisely uneven surfaces and their effects on the 455 slip and eventually increase the accuracy of 456 modeling. The results showed that the use of 457 polynomial functions and linear SVM model in 458 zoning the the area under study with the 459 involvement of Geomorphometric factors of the 460 domains has well identified the points with high 461 landslide potential. Also evaluating the accuracy of 462 the modeling showed that polynomial functions 463 with the overall accuracy of $89 \%$ have shown the 464 areas prone to landslide better than that the linear 465 function which seems to be due to the complex and 466 nonlinear behavior of the variables which are 467 involved in landslide occurrences.

\section{References}

469 -Akgun, A., Sezer, E.A., Nefeslioglu, H.A., Gokceoglu, C., Pradhan, 470 B., 2012. An easy-to-use MATLAB program (MamLand) for the 471 assessment of landslide susceptibilityusing a Mamdani fuzzy 472 algorithm. Computers \& Geosciences, 38, 23-34. 473 doi:10.1016/j.cageo.2011.04.012

474 -Anbalagan, R., 1992. Landslide hazard evaluation and zonation

-Anbalagan, R., 1992. Landslide hazard evaluation and zonation
mapping in mountainous terrain. Engineering Geology, 32, 269-277. doi:10.1016/0013-7952(92)90053-2

- Bui, D., Pradhan, B., Lofman, O., Revhaug, I., Dick, O., 2012. Landslide susceptibil-ity mapping at HoaBinh province (Vietnam) using an adaptive neuro fuzzyinference system and GIS.Computers and Geosciences. 45.199-211. doi:10.1016/j.cageo.2011.10.031

- Chung, C., Fabbri, A., 2003. Validation of spatial prediction models for landslide hazard mapping. Natural Hazards, 30, 451-472. doi: 10.1023/B:NHAZ.0000007172.62651.2b

- Dai, F.C., Lee, C.F., Li, J., Xu, Z.W., 2001. Assessment of landslide susceptibility on the natural terrain of Lantau Island, Hong Kong. Environmental Geology, 40, 381-391. doi: $10.1007 / \mathrm{s} 002540000163$ 

produce landslide susceptibility map of a landslide prone area (West Black Sea Region, Turkey). Engineering Geology, 75, 229-250. doi:10.1016/j.enggeo.2004.06.001

- Fell, R., Corominas, J., Bonnard, C., Cascini, L., Leroi, E., Savage, W., 2008. Guidelines for landslide susceptibility, hazard and risk zoning for land-use planning. Engineering Geology, 102, 99-111. doi:10.1016/j.enggeo.2008.03.014

-Fisher, P., Wood, J., Cheng, T., 2004. Where is Helvellyn? Fuzziness of Multiscale Landscape Morphometry. Transactions of the Institute of British Geographers, 29 (1), 106-128. DOI: 10.1111/j.0020-2754.2004.00117.x

-Frattini, P., Crosta, G., Carrara, A., 2010. Techniques for evaluating the performance of landslide susceptibility models. Engineering Geology, 111, 62-72. doi:10.1016/j.enggeo.2009.12.004

Guzzetti, F., Reichenbach, P., Ardizzone, F., Cardinali, M., Galli, M., 2006. Estimating the quality of landslide susceptibility models. Geomorphology, 81, 166-184. doi:10.1016/j.geomorph.2006.04.007 - Lee, S., Ryu, J., Won, J., Park, H., 2004. Determination and application of the weightsfor landslide susceptibility mapping using an artificial neural network. Engineering Geology, 71, 289-302. doi:10.1016/S0013-7952(03)00142-X

- Ling Peng, A.B., RuiqingNiu, A., Bo Huang, C., XuelingWu,A., YannanZhao,A., RunqingYe,D., 2014. Landslide susceptibility mapping based on rough set theory and support vector machines: A case of the Three Gorges area, China.Geomorphology, 204, 287301. doi:10.1016/j.geomorph.2013.08.013

-Lulseged, A., Yamagishi, H., Ugawa, N., 2004. Landslide susceptibility mapping using GIS-based weighted linear combination, the case in Tsugawa area of Agano river. Niigata Prefecture, Japan, Landslide, 1, 73- 81. Doi: 10.1007/s10346-0030006-9

-Nadim, F., Kjekstad, O., Peduzzi, P., Herold, C., Jaedicke, C., 2006. Global landslide andavalanche hotspots. Landslides, 3, 159-173. Doi:10.1007/s10346-006-0036-1

-Nefeslioglu, H.A., Gokceoglu, C., Sonmez, H., 2008. An assessment on the use of logis-tic regression and artificial neural networks with different sampling strategiesfor the preparation of landslide susceptibility maps. Engineering Geology, 97, 171-191. doi:10.1016/j.enggeo.2008.01.004

-Nefeslioglu, H.A., Sezer, E., Gokceoglu, C., Bozkir, A.S., Duman, T.Y., 2010. Assessmentof landslide susceptibility by decision trees in the metropolitan area of Istanbul,Turkey. Mathematical Problems in Engineering, 1-15. doi:10.1155/2010/901095

- Oh, H.-J., Pradhan, B., 2011. Application of a neuro-fuzzy model to landslide-susceptibility mapping for shallow landslides in a tropical hilly area. Computers\& Geosciences, 37, 1264-1276. doi:10.1016/j.cageo.2010.10.012

- Pike, R.J., 2000. Geomorphology - Diversity in quantitative surface analysis. Progress in Physical Geography, 24, 1-20. doi: $10.1177 / 030913330002400101$

-Pourghasemi, H.R., Mohammady, M., Pradhan, B., 2012. Landslide susceptibility mapping using index of entropy and conditional probability models in GIS: Safarood Basin, Iran. Catena, 97, 71-84. doi:10.1016/j.catena.2012.05.005

- Pradhan, B., 2013. A comparative study on the predictive ability of the decisiontree, support vector machine and neuro-fuzzy models in landslide susceptibilitymapping using GIS. Computers \& Geosciences, 51, 350-365. doi:10.1016/j.cageo.2012.08.023

- Pradhan, B., Lee, S., Buchroithner, M., 2009. Use of geospatial data for the develop-ment of fuzzy algebraic operators to landslide hazard mapping: a case study in Malaysia. Applied Geomatics, 1, 315. DOI 10.1007/s12518-009-0001-5

- Saito, H., Nakayama, D., Matsuyama, H., 2009. Comparison of landslide susceptibilitybased on a decision-tree model and actual landslide occurrence: theAkaishiMountains, Japan.Geomorphology, 109, 108-121. doi:10.1016/j.geomorph.2009.02.026
- Talbot, C.J., Alavi, M., 1996. The past of a future syntaxis across the Zagros. Geological Society, London, Special Publications, 100, 89 - 109. Doi: 10.1144/GSL.SP.1996.100.01.08

-Talebi, A., Troch, P. A., Uijlenhoet, R., 2008. A steady state analytical slope stability model for complex hillslope, Hydrological Processes, 22, 546-553. DOI: 10.1002/hyp.6881

-Taner San, B., 2014. An evaluation of SVM using polygon-based random sampling inlandslide susceptibility mapping: The Candir catchment area(western Antalya, Turkey). International Journal of Applied Earth Observation and Geoinformation, 26, 399-412. doi:10.1016/j.jag.2013.09.010

Vapnik, V., 1995. The Nature of Statistical Learning Theory. Springer-Verlag, Inc., New York

Wan, S., 2009. A spatial decision support system for extracting the core fac-tors and thresholds for landslide susceptibility map. Engineering Geology, 108, 237-251. doi:10.1016/j.enggeo.2009.06.014

- Wood, J., 1996. Scale-based characterization of digital elevation models. In: Parker, D. Innovations in GIS, Tayler and Francis, London, 163-175.

Yalcin, A., 2008. GIS-based landslide susceptibility mapping using analytical hierarchy process and bivariate statistics in Ardesen (Turkey): comparisons of results and confirmations. Catena, 72, 112. doi:10.1016/j.catena.2007.01.003

- Yamani, M., Ahmadabadi, A., Zare, G.R., 2013. Application of support vector machine algoritm in landslide hazard zoning (Case study: Darake of watershed).Geoghraphy and Environmental Hazards, $\quad 3$, 125-142. https://www.sid.ir/en/journal/ViewPaper.aspx?id=295973

Yamani, M., Shamsipour, A.A., Gourabi, A., Rahmati, M., 2014. Determining landslide zones in Khorramabad - Pole Zaal freeway by using Hierarchical Analysis - Fuzzy Logic method. Applied Research of Geographic Sciences, 32, 27-44. https://www.sid.ir/en/journal/ViewPaper.aspx?id=403580

- Yamani, M., Shamsipour., Rahmati, M., 2014. The bounding of the present and quaternary zones of climate and morphogenesis processes in Khorramabad - Pole Zaal freeway. Quantitative Geomorphological Researches, 2, $\quad 90 \quad-\quad 103$. http://www.geomorphologyjournal.ir/article 77953.html

Yao, X., Tham, L.G., Dai, F.C., 2008. Landslide susceptibility mapping based on supportvector machine: a case study on natural slopes of Hong Kong, China. Geomorphology, 101, 572-582. doi:10.1016/j.geomorph.2008.02.011

-Yeon, Y.K., Han, J-G., Ryu, K.H., 2010. Landslide susceptibility mapping in Injae,Korea, using a decision tree. Engineering Geology, 116, 274-283. doi:10.1016/j.enggeo.2010.09.009

Yesilnacar, E., Topal, T., 2005. Landslide susceptibility mapping: a comparison oflogistic regression and neural networks methods in a medium scale study, Hendek region (Turkey). Engineering Geology, 79, 251-266. doi:10.1016/j.enggeo.2005.02.002

-Yilmaz, I., 2009. Landslide susceptibility mapping using frequency ratio, logisticregression, artificial neural networks and their comparison: a case study fromKat landslides (Tokat, Turkey). Computers \& Geosciences, 35, 1125-1138. doi:10.1016/j.cageo.2008.08.007

-Marjanovi'c, M., Kova“cevi'c, M., Bajat, B., Vo`zenílek, V., 2011. Landslide susceptibility assessment using SVM machine learning algorithm. Engineering Geology, 123 (3), 225-234. doi:10.1016/j.enggeo.2011.09.006

- Talebi, A., Uijlenhoet, R ., Troch, P., 2008. A low dimensional physicaly based model of hydrologic control of shallow landsliding on complex hill slopes. Earth Surf. Process. Landforms, 33, 19641976. DOI: $10.1002 /$ esp. 1648

Xu, C., Dai, F., Xu, X., Lee, Y.H ., 2012. GIS-based support vector machine modeling of earthquake-triggered landslide susceptibility in the Jianjiang River watershed, China. Geomorphology, 145-146, 70-80. doi:10.1016/j.geomorph.2011.12.040 


\section{Figures}

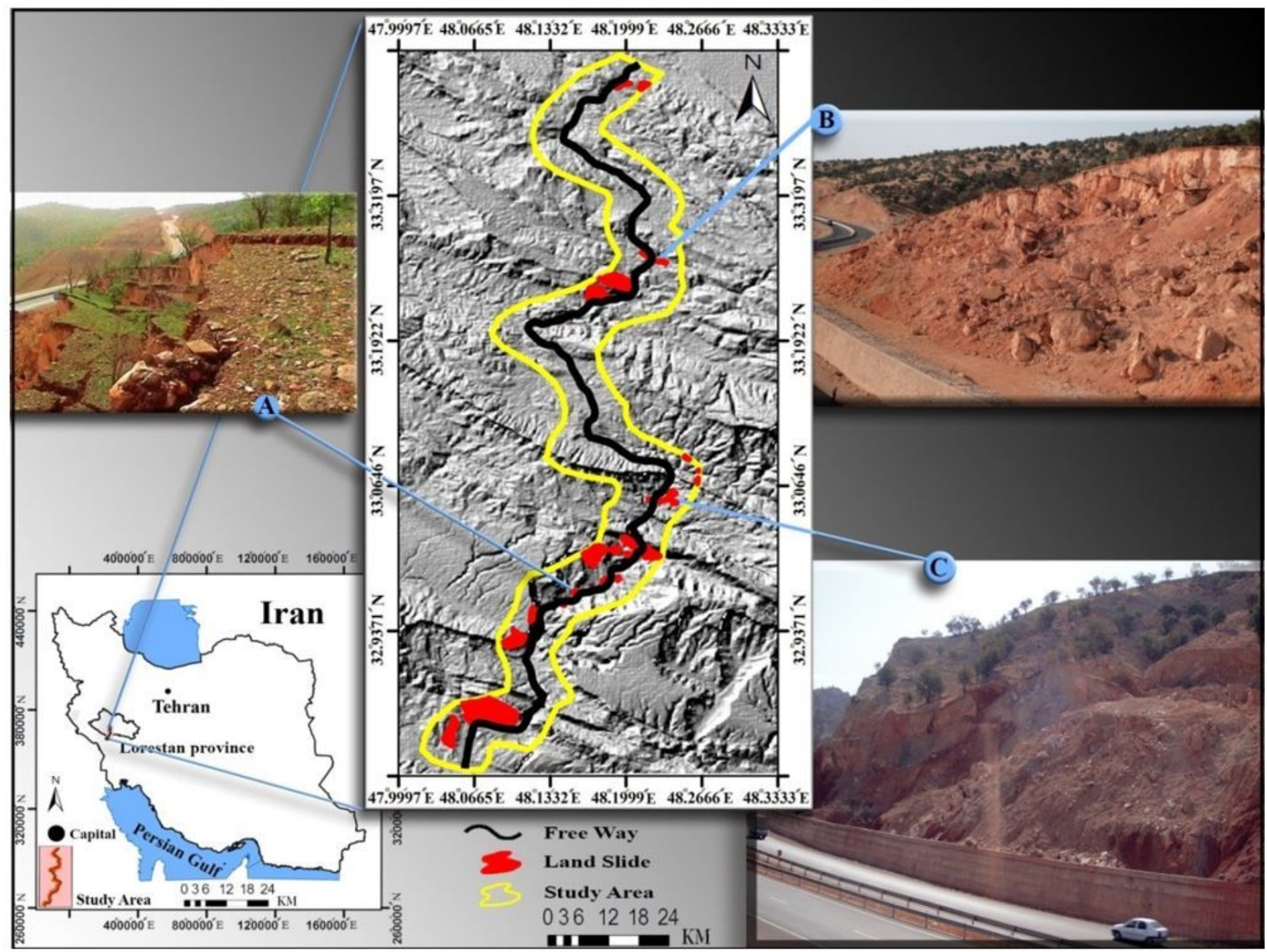

Figure 1

Location map of the area in Lorestan province and dispersion of sliding. 


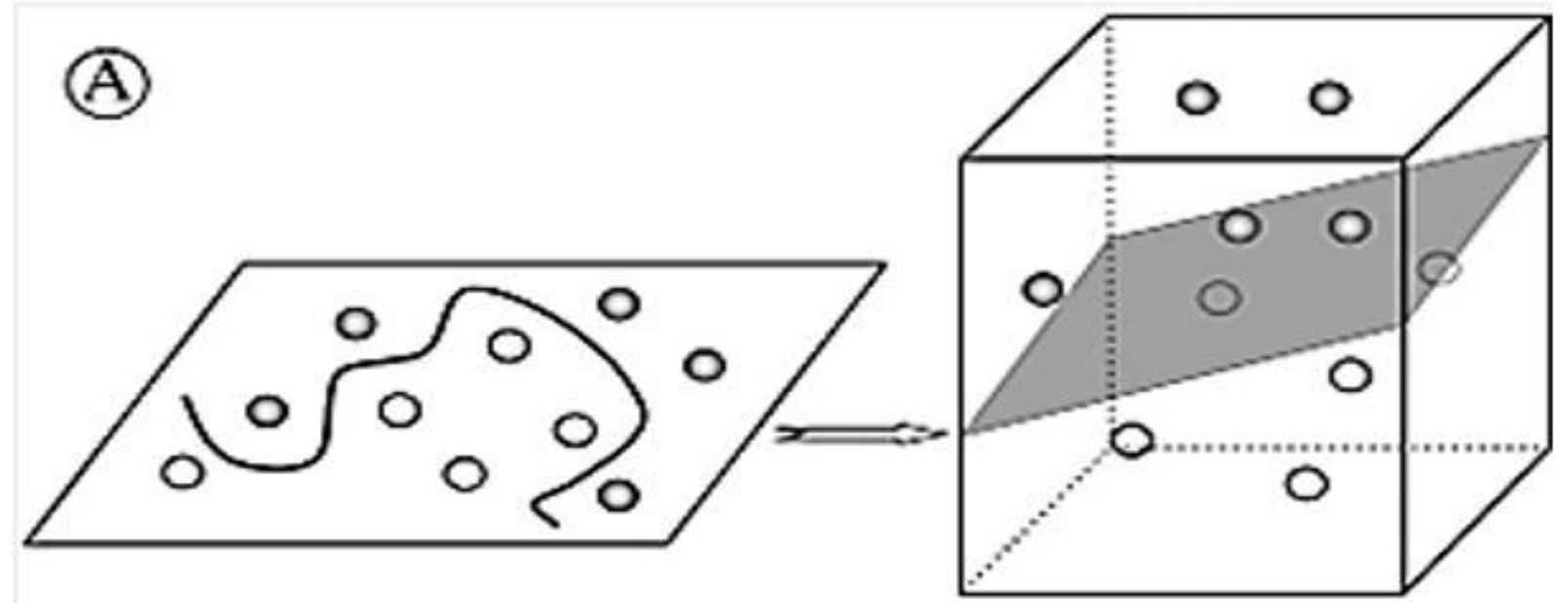

(B)

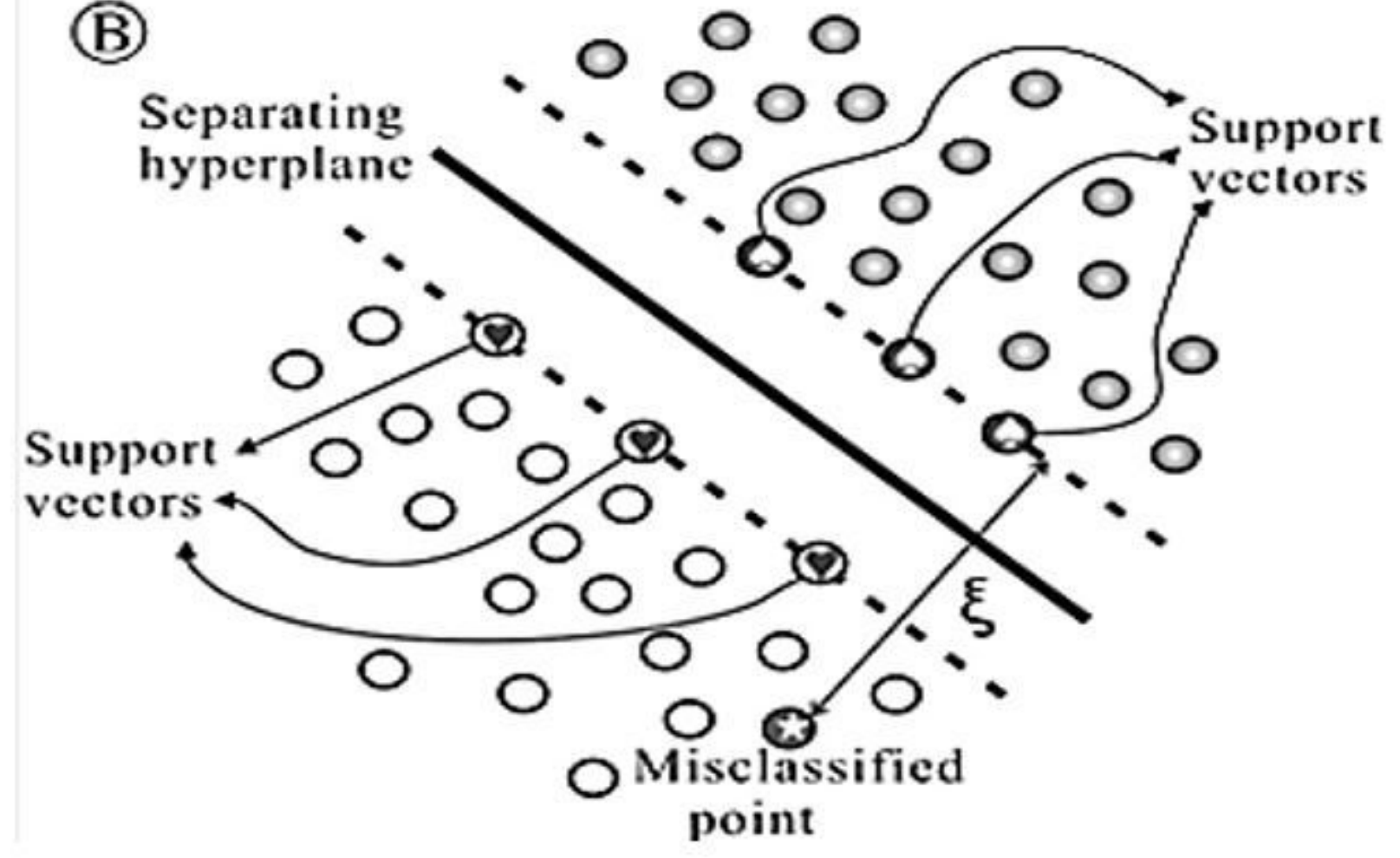

Figure 2

Image of the principles of $S V M(A)$ n-dimensional Page differences between the two classes with a maximum distance(B) The inseparable and imprecise variables. 


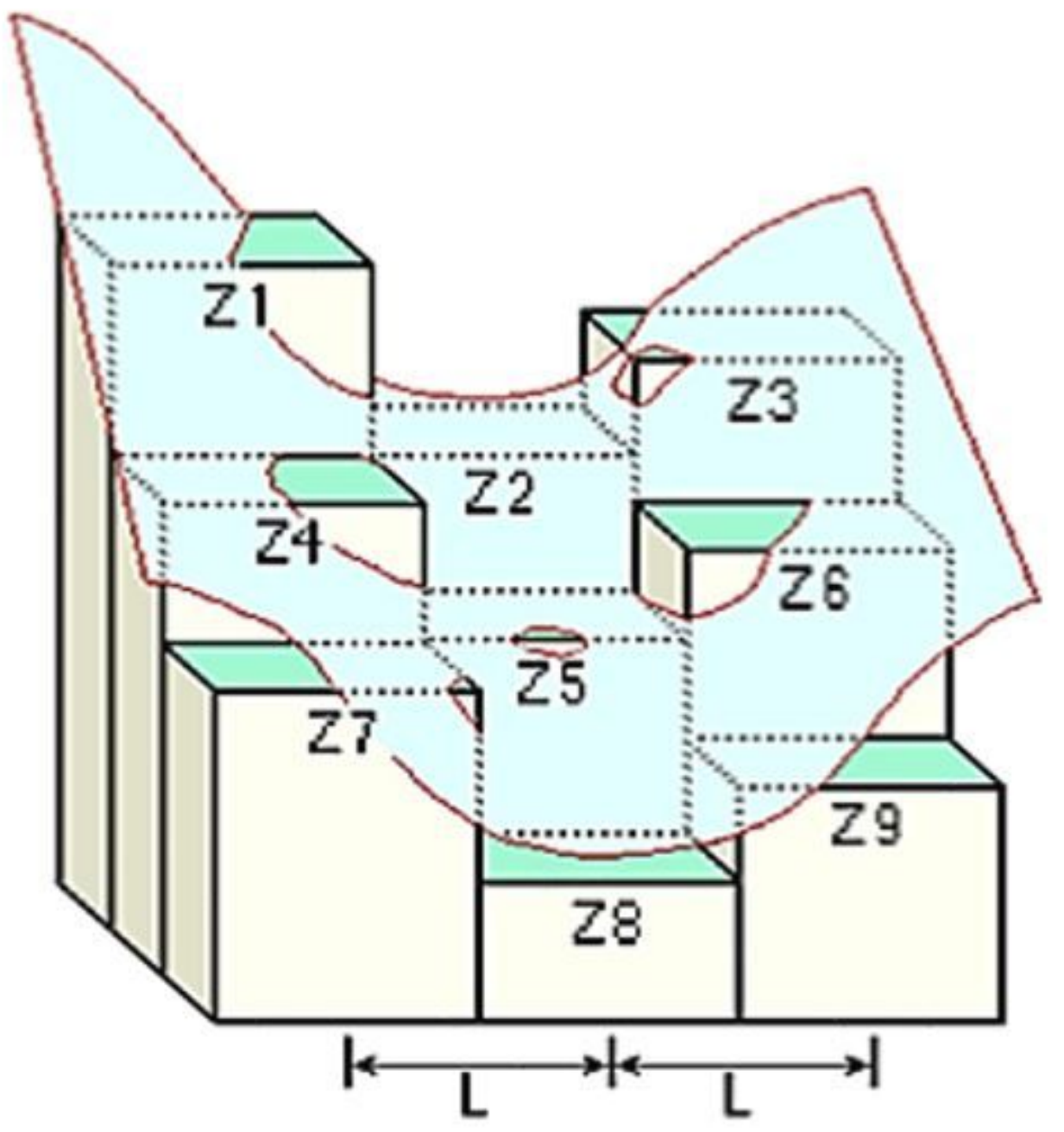

Figure 3

Schematic representation of the parameters used in calculating the overall of curvature. 


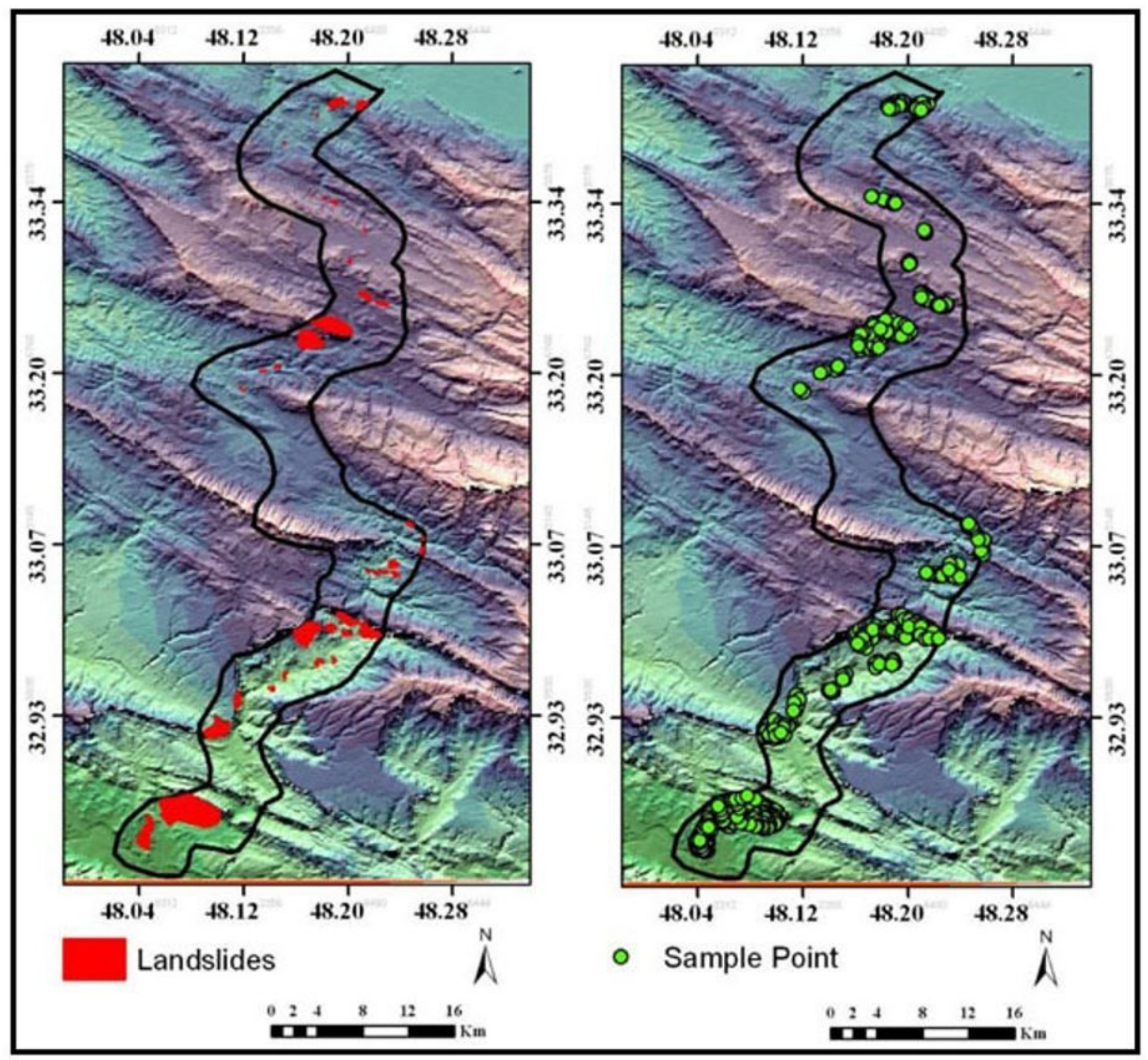

Figure 4

Distribution of landslides and training samples in the study area. 

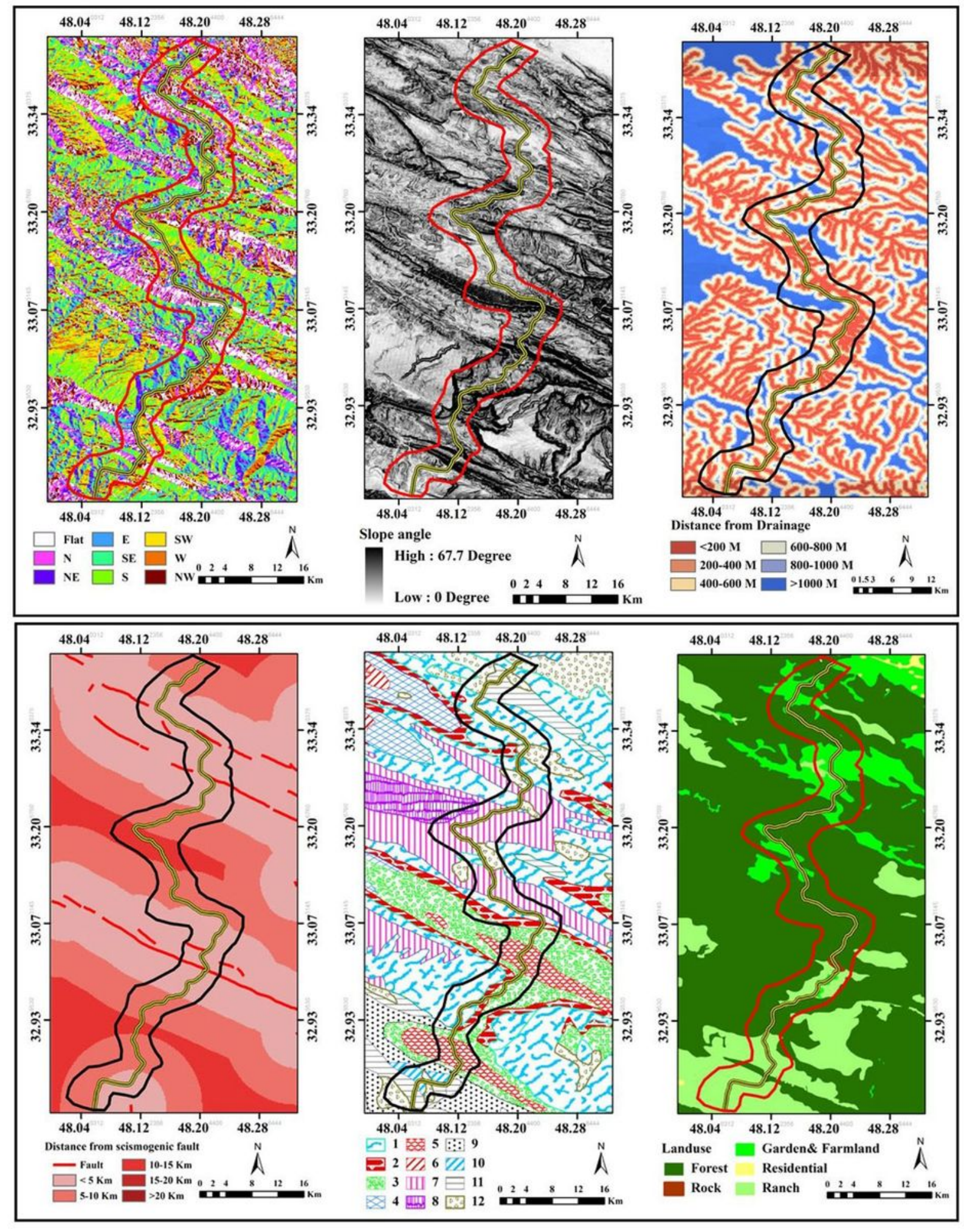

Figure 5

Landslide control variables in the study area. 

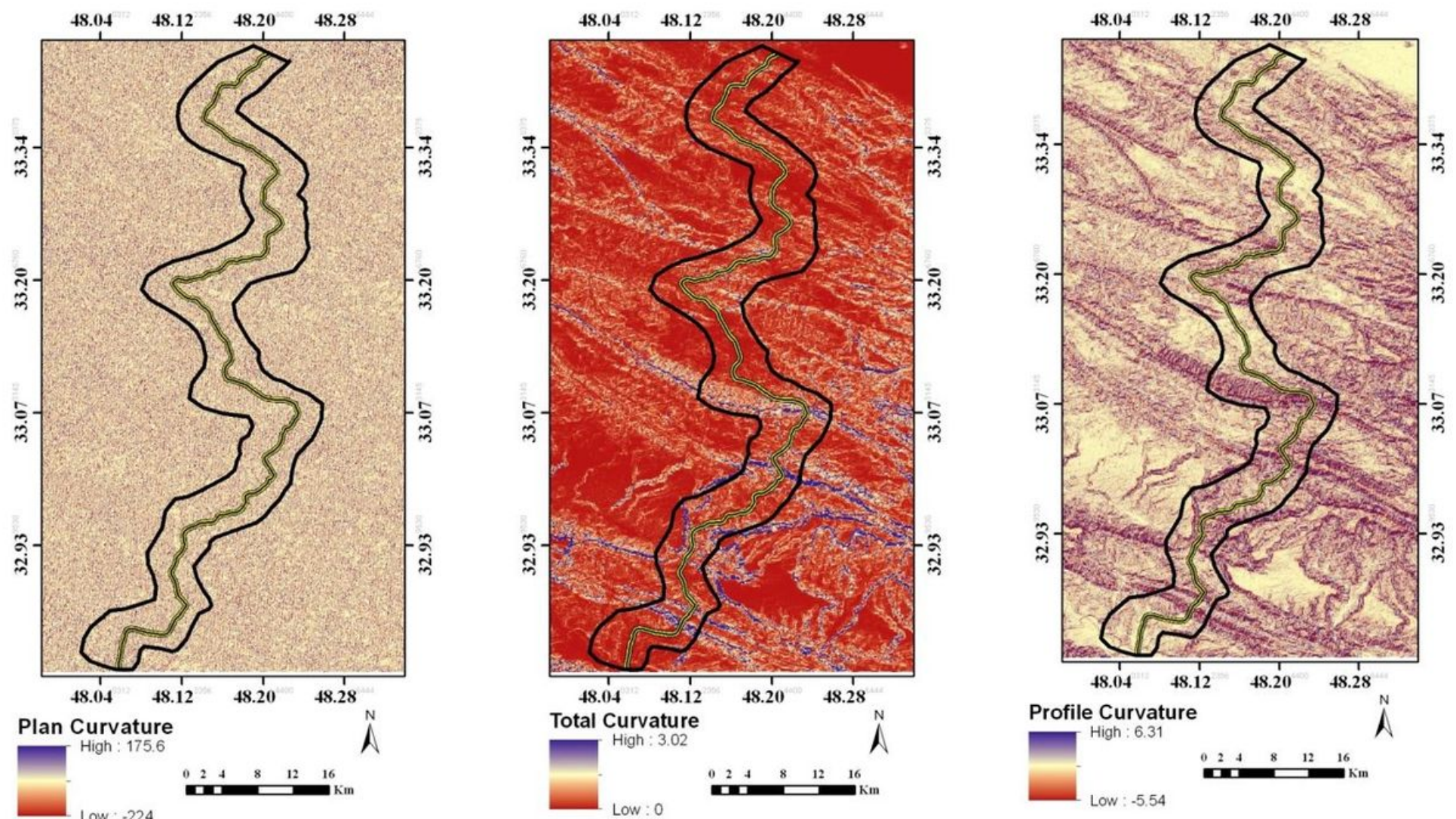

Figure 6

Geomorphomety variables controlling landslides in the study area. 

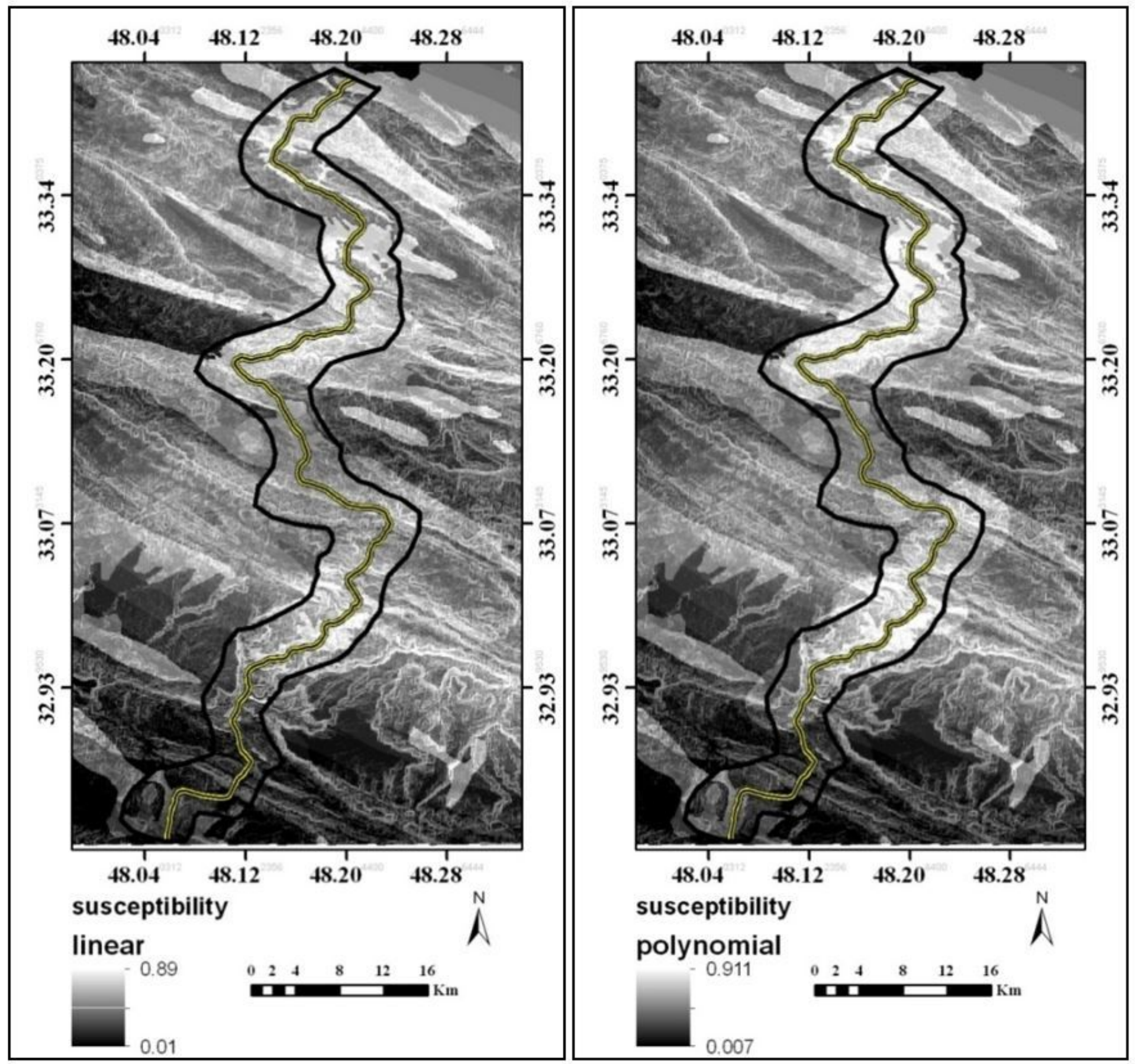

Figure 7

landslide susceptibility based on linear and polynomial function and SVM model in the study area. 